\begin{tabular}{|c|c|}
\hline CRITICAL $\left.\right|_{\text {PARTNERSHIP FUND }} ^{\text {ECOSYSTEM }}$ & $\begin{array}{l}\text { Western Ghats } \\
\text { Special Series }\end{array}$ \\
\hline
\end{tabular}

\title{
A NEW SPECIES AND NEW RECORDS OF PARASITIC WASPS (HyMENOPTERA: PTEROMALIDAE) OF WOOd BORING BEeTLES FROM SOUTHERN WESTERN GHATS, KERALA, INDIA
}

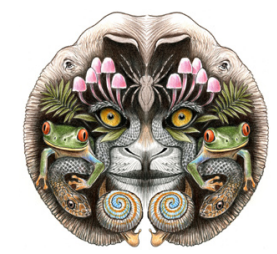

ISSN

Online 0974-7907 Print 0974-7893

OPEN ACCESS

\author{
P.M. Sureshan ${ }^{1} \&$ Dhanya Balan ${ }^{2}$ \\ 1,2 Zoological Survey of India, Western Ghats Regional Centre, Jafferkhan Colony, Eranhipalam P.O., Kozhikode, Kerala \\ 673006, India \\ ${ }^{1}$ pmsuresh43@yahoo.com (corresponding author), 2'dhanyamkrishna@gmail.com
}

\begin{abstract}
A new species of Pteromalidae (Hymenoptera: Chalcidoidea) parasitising wood boring beetles, Cleonymus kamijoi, and two species of Pteromalidae, Trigonoderus pulcher Walker and male of Heydenia tuberculata Sureshan are reported for the first time from the southern Western Ghats, Kerala. The genus Trigonoderus Westwood is reported for the first time from India and the male of Heydenia tuberculata Sureshan is reported and described for the first time.
\end{abstract}

Keywords: Cleonymus, Heydenia, Kerala, new record, new species, southern Western Ghats, Trigonoderus.

Abbreviations: F1-F6 - Funicular segments 1 to 6; MV - Marginal vein; OOL - Ocellocular distance; PMV - Post marginal vein; POL - Post-ocellar distance; SMV - Submarginal vein; STV - Stigmal vein; T1-T7 - Gastral tergites 1-7; ZSIK - Zoological Survey of India, Western Ghat Regional Centre, Kozhikode, Kerala, India.
During faunal exploration surveys conducted in the forested tracts of southern Western Ghats some rare and interesting species of insect parasitoids belonging to the family Pteromalidae were collected, these include one new species of the genus Cleonymus Latreille and the other species were Trigonoderus pulcher Walker and Heydenia tuberculata Sureshan. Cleonymus is a rare genus known for 42 species globally of which only four species are known from the Oriental Region and one $C$. keralicus Narendran \& Rajmohana from India. They are primary parasitoids of wood boring beetles of the families Anobiidae, Bostrichidae, Buprestidae, Anthribidae, Cerambycidae, Curculionidae and Scolytidae (Gibson 2003). The second Indian species, Cleonymus kamijoi is described here as new to science. The present species is based on a single specimen which shows unique

DOI: http://dx.doi.org/10.11609/JoTT.o3272.4537-41 | ZooBank: urn:Isid:zoobank.org:pub:CB99E6EE-4BFA-4581-81AF-4320EB3F0A02

Editor: Hui Xiao, Chinese Academy of Sciences, Chaoyang, China.

Date of publication: 26 July 2013 (online \& print)

Manuscript details: Ms \# 03272 | Received 27 August 2012 | Final received 25 April 2013 | Finally accepted 03 July 2013

Citation: Sureshan, P.M. \& D. Balan (2013). A new species and new records of parasitic wasps (Hymenoptera: Pteromalidae) of wood boring beetles from southern Western Ghats, Kerala, India. Journal of Threatened Taxa 5(11): 4537-4541; http://dx.doi.org/10.11609/JoTT.03272.4537-41

Copyright: (C) Sureshan \& Balan 2013. Creative Commons Attribution 3.0 Unported License. JoTT allows unrestricted use of this article in any medium, reproduction and distribution by providing adequate credit to the authors and the source of publication.

Funding: The work is based on the annual research programme of Zoological Survey of India, WGRC, Calicut (Ministry of Environment \& Forests, Govt. of India)

Competing Interest: None.

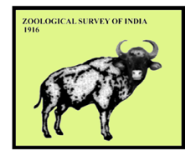

Acknowledgements: We are grateful to Dr. K. Venkataraman, Director, Zoological Survey of India, Kolkata for providing all the facilities for the work and encouragement. PMS is grateful to Dr. John S. Noyes, The Natural History Museum, UK and Dr. T.C. Narendran, Professor (Emeritus), Zoological Survey of India, Kozhikode for providing valuable reprints for reference. We are also thankful to Mr. C. Bijoy, Junior research fellow, ZSI, Kozhikode for helping to prepare the photographs. Thanks are also due the Chief Wildlife Warden, Kerala and the forest officials of Chinnar Wildlife Sanctuary, Mannavanshola National Park and Eravikulam National Park for granting permission to conduct faunistic surveys and make collections and for the various help rendered during the field work.

The publication of this article is supported by the Critical Ecosystem Partnership Fund (CEPF), a joint initiative of I'Agence Française de Développement, Conservation International, the European Commission, the Global Environment Facility, the Government of Japan, the MacArthur Foundation and the World Bank. 
features distinguishing it from other related species and all efforts to collect further specimens did not yield any additional material.

Trigonoderus pulcher (Walker), collected from the core area of Eravikulam National Park where temperate climatic conditions prevail during most of the seasons. Heydenia Forster is known for 18 global species of which three are from India. They are parasitoids of larvae and pupae of wood-boring beetles of the families Buprestidae, Cerambycidae, Curculionidae and Scolytidae. The Indian species $H$. tuberculata Sureshan, 2002 was described from the female holotype collected from the forested tracts of southern Western Ghats of Kodagu District, Karnataka, India. The male specimen of the species is reported here for the first time.

The specimens of the present study are deposited in the Zoological Survey of India, Western Ghat Regional Centre, Kozhikode (ZSIK). The morphology used in this paper follows generally that of Gibson (1997).

\section{Cleonymus kamijoi sp. nov.}

(Figs. 1-2, Image 1)

urn:Isid:zoobank.org:act:97285470-2288-49A8-B58C-16EABDDC6D69

Material examined: Holotype: ZSI/WGRS/IR-

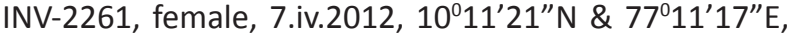
Mannavanshola National Park, Idukki, Kerala, India, coll. K. Rajmohana.

Etymology: The species is named in honour of $\mathrm{Dr}$. Kazuaki Kamijo, Bibai, Hokkaido Japan for his remarkable contributions on the systematic studies on Japan Pteromalidae.

Description: Female: Length: $5 \mathrm{~mm}$. Head and mesosoma except propodeum dark green with bronzy reflection, propodeum bright metallic blue; gaster dark brownish-black with metallic blue reflection on $\mathrm{T} 1$ and T2 completely and hind part of other tergites dorsally; all coxae and hind femora concolorous with mesosoma, rest of legs yellowish-brown except tibiae and distal tarsal segments brownish-black; eyes and ocelli pink; antennae blackish-brown except scape basally and F5,F6 testaceous; tegulae testaceous, veins brown, wings hyaline with two brown infumate patches one below parastigma and other below STV which are incompletely interconnected, apical margin with pale brown infumation and small brown patch in the lower margin below parastigma as seen in Image 1 .

Head: Uniformly raised reticulate, reticulation finer on clypeus and paraclypeal area; scrobe as deep depressions above each torulus with inter-antennal region slightly raised, parascrobal region little raised near

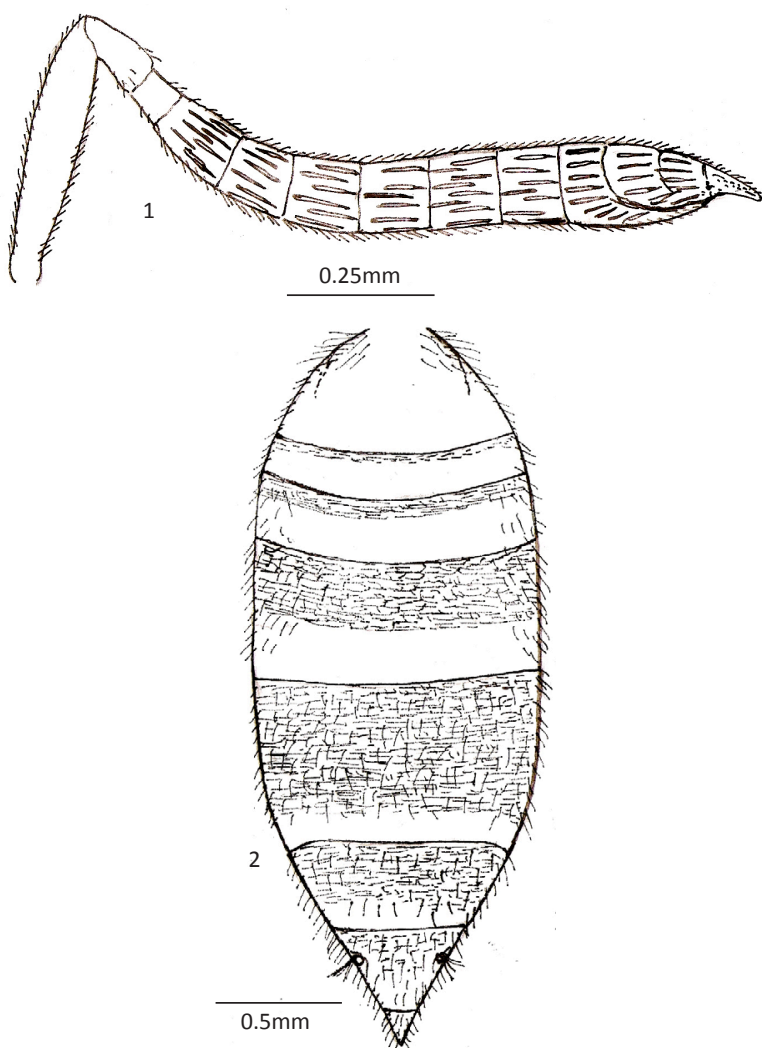

Figures 1-2. Cleonymus kamijoi sp. nov. Female 1 - Antenna; 2 - Gaster in dorsal view

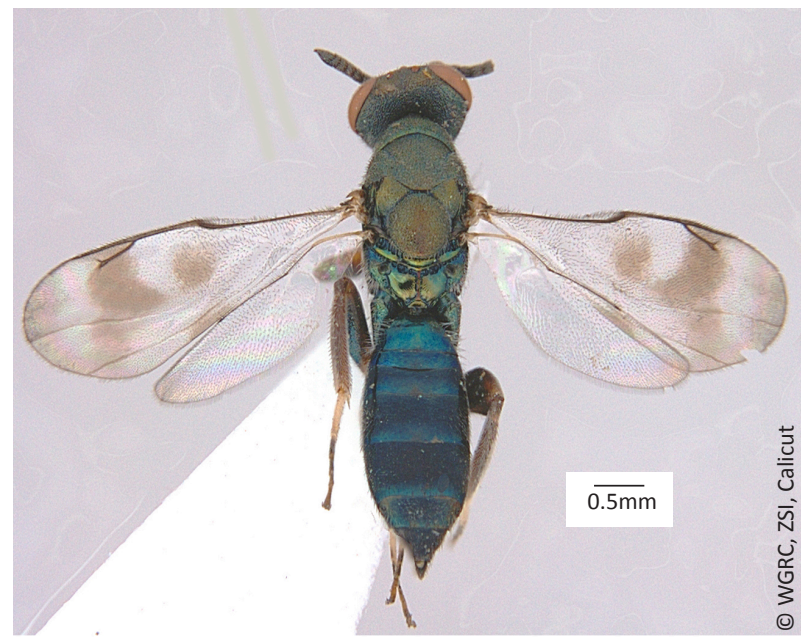

Image 1. Cleonymus kamijoi sp. nov. Body in dorsal view.

toruli, pubescence dense on lower face; eyes separated $1.7 x$ their length at level of trouli. In dorsal view head width 2.6x width; POL $2 \times$ OOL; eyes pubescent; temple very narrow; antennae (Fig. 1) inserted slightly below level of lower margin of eyes; scape $0.7 x$ as long as eye, pedicel plus flagellum $0.9 x$ width of head; pedicel $1.9 x$ as long as broad, anellus slightly longer than half of peidcel 
and slightly longer than wide (5.5:4.5), sutures between funicular segments rather obscure; all funicular segments with two rows of sensillae and with short dense setae.

Mesosoma: $1.71 \mathrm{x}$ as long as broad; pronotum $0.6 \mathrm{x}$ as long as broad, shorter than mesoscutum (20:24). Mesoscutum 2xas broad as long; pronotum, mesoscutum and scutellum coarsely reticulate; pronotum with a narrow smooth strip posteriorly, pubescence rather sparse. Scutellum highly convex, almost round, as long as broad, with dense setae on posterior margin. Dorsellum smooth and shiny. Propodeum medially $0.53 x$ as long as scutellum, almost completely shiny except finely engraved reticulate on callus and near median carina; median carina strong, complete, joined with strong posterior transverse carina, foveae on anterior margin well developed, foveae on either side of medina carina distinct; spiracles large, oval, separated from hind margin of metanotum less than its diameter, plicae absent, plical area with foveae, callus densely hairy. Prepectus broad similarly sculptured as on Pronotum. Mesospleuron and metapleuron densely reticulate except upper mesepimeron smooth. All coxae and femora strongly engraved reticulate, hind femur swollen, $2.5 x$ as long as broad, ventral edge finely but distinctly serrate; hind tibia with two unequal spurs. Forewing length $2.53 \mathrm{x}$ width, almost completely hairy, costal cell hairy on the upper half. Relative lengths of SMV 33, MV 18, PMV 15, STV 10.

Metasoma: Gaster (Fig. 2)1.4x as long as mesosoma, $2.3 \mathrm{x}$ as long as broad in dorsal view; T1 with dense pubescence laterally in the base, T1 and T2 almost completely smooth, T3 transversely aciculate strigose basally, T4 3/4 portion, T5 and T6 almost completely except a distal smooth strip, epipygium completely aciculate reticulate; T5 $1.23 \mathrm{x}$ as long as T4, posterior margin of tergites almost straight; hypopygium reaching hind margin of T3.

Male: Unknown.

Remarks: In the key to oriental species of Cleonymus (Narendran \& Rajmohana 2008), this species runs into couplet three and closely resembles $C$. grandiceps Xiao et Huang in general morphology but differs from it in having antennae with pedicel shorter than anellus and F1 combined, F1 longer than broad, pedicellus plus flagellum $0.9 x$ head width, pronotum only little shorter than mesoscutum $(20: 24)$ and $0.6 x$ as long as broad, mesoscutum $2 \mathrm{x}$ as broad as long, forewing with infumate bands not clearly joined in the middle, and the one below parastigma not touching the lower margin , separated from the small band on hind margin of wing and in large size ( $5 \mathrm{~mm}$ ), (in grandiceps antennae with pedicel longer than anellus and F1 combined, all funicular segments quadrate, pedicel plus flagellum distinctly longer than head width, pronotum about half as long as mesoscutum and $0.4 \mathrm{x}$ as long as broad, forewing with infumate bands joined in the middle and the band below parastigma touching lower and upper margin). This species also resembles $C$. serrulatus Kamijo, 1996 and C. togashii Kamijo, 1996 in the nature of infumation on forewing, body colour, nature of gaster and nature of hind femur but differs from them as follows; in C. serrulatus Kamijo frons in front of ocelli very weakly raised reticulate, F1 a little longer than pedicel and about as long as broad, scutellum often not convex with dense setae, propodeum with foveae along either side of median carina almost absent, hind transverse carina thin and gaster $1.8-2.1 \mathrm{x}$ as long as broad (in kamijoi sp. nov. frons in front of ocelli distinctly raised reticulate, F1 distinctly longer than pedicel, scutellum highly convex with less setae, propodeum with foveae along either side of median carina distinct, hind transverse carina strong and gaster $2.3 \mathrm{x}$ as long as broad). The new species differs from $C$. togashii in body colour which is mostly dark green with bronzy reflection, propodeum bright metallic blue, gaster dark brownishblack with metallic blue reflection on $\mathrm{T} 1$ and $\mathrm{T} 2$, POL 2xOOL, F1 distinctly longer than broad with two rows of sensillae, mesosoma $1.71 x$ as long as broad, gaster $2.3 x$ as long as broad ( in togashii body bronzy; gaster with T2-T7 dark purplish, F1-F6 about quadrate, F1 with a row of numerous sensillae, mesosoma $2 x$ as long as broad and gaster 2.5-2.6x as long as broad). From the Indian species C.keralicus Narendran and Rajmohana, 2008 the new species differs in the nature of colour, different type infumation on forewing different antenna, mesosoma and gaster.

\section{Trigonoderus pulcher Walker (Image 2)}

Trigonoderus pulcher Walker, 1836. Ent. Mag., 4:16. F, Lectotype (BMNH)

Trigonoderus contemptus Walker, 1836. Ent. Mag., 4: 22. Synonymized by Graham 1969: 101.

Material examined: ZSI/WGRS/ IR-INV-2262, female, 10.iv.2012, $10^{\circ} 13^{\prime} 16^{\prime \prime} \mathrm{N} \& 77^{\circ} 4^{\prime} 42^{\prime \prime} \mathrm{E}$, Eravikulam hut area, Eravikulam National Park, Idukki, Kerala, India, coll. P.M. Sureshan.

Description: Female: Length $4.1 \mathrm{~mm}$. Head and mesosoma metallic bluish green, with strong brassy reflection on dorsal part of mesosoma, gaster brown with metallic blue reflection on basal part of tergites; eyes cupreous, ocelli pink, antennae with scape 


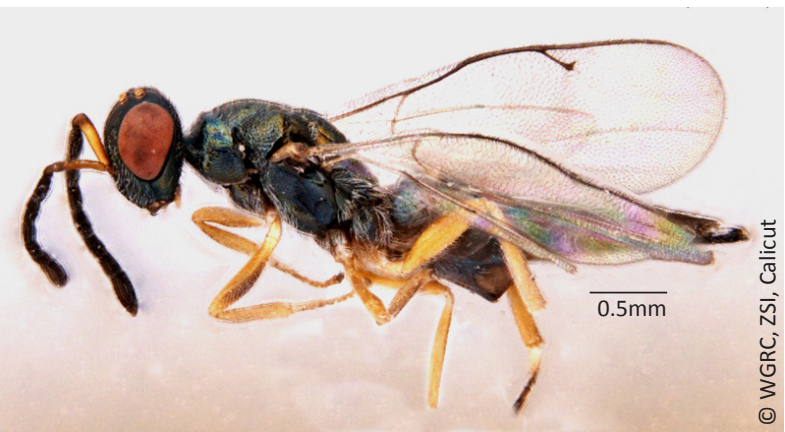

Image 2. Trigonoderus pulcher Walker, female, body in profile.

testaceous, pedicel brown, rest of antenna blackishbrown, mandibles dark brown; legs except coxae and distal tarsal segments testaceous, coxae pale brown except hind coxae darker, distal tarsal segments of mid and hind legs brown; tegulae testaceous, veins brown, wings hyaline, pubescence brown.

Head: In dorsal view width 2x length; POL 1.4x OOL, reticulation fine on vertex and occipital area; temples round, $0.3 x$ eye length. In front view, head width $1.3 x$ height, gena finely reticulate, eyes separated by their individual height at level of toruli, eye length $1.5 \mathrm{x}$ width (in profile). Clypeus with distinct blunt median tooth, clypeus and adjacent areas including malar space polished, rest of face moderately reticulate with broad meshes; malar groves distinct, tentorial pits distinct, malar space half as long as eye, area just below toruli conically elevated; scrobe deep, almost round $1.15 \mathrm{x}$ as broad as long, scrobal area almost fine, with a faint slit like median groove; pubescence moderately long and dense on lower face. Antennae inserted below middle of face above lower ocular line; the distance between lower margin of toruli to anterior margin of clypeus half that of distance between it and lower margin of front ocellus; scape $0.8 x$ eye length, anelli transverse, pedicel plus flagellum $1.54 \mathrm{x}$ width of head, pedicel $1.5 \mathrm{x}$ as long as broad and 0.52x F1; F1 longest, 1.31x F2, clava 2x as long as preceding segment. Relative lengths scape 29, pedicel 9, F1 17, F2 13, F3, F4 12.5, F5, F6 10.5, clava 21; all funicular segments with 3 rows of sensillae, micropilosity area of clava restricted in the tip.

Mesosoma: $0.61 \mathrm{x}$ as long as gaster. Pronotum $1.4 \mathrm{x}$ as broad as long in dorsal view, finely and irregularly reticulate on collar, transversely reticulate on neck and lateral panel, distinctly carinate anteriorly in the centre. Mesoscutum distinctly raised reticulate with broad meshes, 1.7x as broad as long, notauli complete, deep. Scutellum little convex, as long as broad, reticulation distinct and coarse on area in front of frenum and meshes smaller and finer on frenal area, frenal groove deep and distinct, posterior rim with distinct foveae. Dorsellum polished, in the form of a semicircular lobe. Propodeum medially half as long as scutellum, median carina distinct, almost completely polished except for the fine aciculation on callus; plicae distinct, present only in the posterior half; spiracles large, oval, separated from hind margin of metanotum by little less than its diameter (4:5.5), anterior submedian foveae and post spiracular sulcus deep; prepectus reticulate punctuate on the hind part, anterior half smooth. Mesopleuron with upper mesepisternum reticulate punctate, lower mesepisternumaciculate, mesepimeronandmetapleuron almost fine. Forewing with basal cell completely hairy, speculum almost absent, discal pubescence otherwise dense, basal setal fold distinct, costal cell hairy in the upper half and completely pubescent distally. Relative lengths SMV 52, MV 30, PMV 41, STV 9.5. All coxae finely aciculate reticulate and densely hairy, hind tibia with two unequal spurs, densely setate. Relative lengths: hind coxa 23, femur 40, tibia 48, tarsus 42.

Metasoma: Petiole transverse, gaster lanceolate, $1.3 x$ as long as head plus mesosoma combined, and $3.13 x$ as long as broad in dorsal view, dorsally collapsing; ovipositor distinctly exerted out. Hind margin of T1 incised medially, T2-T4 straight, T5 distinctly concave. Tergites laterally with long white pubescence, T1-T2 polished, T3-T5 finely aciculate in the basal part, T6 finely and transversely reticulate, epipygium $1.43 \mathrm{x}$ as long as broad in dorsal view, hypopygium reaching hind margin of T3.

Distribution: Japan, Europe, India (present study).

Remarks: In the key to Japanese species by Kamijo (2000) the present specimen keyed out in to T. pulcher Walker and match with morphology of Japanese specimens. In the present specimen combined length of pedicellus plus flagellum $1.54 x$ breadth of head (1.3-1.53x in Japanese and 1.25-1.35x in European specimens), F1 $2.3 x$ as long as broad (1.95-2.9x in Japanese and 1.8-2.3x in European) F6 1.4x as long as broad (1.2-1.8x in Japanese and 1-1.55x in European), clava $2.2 x$ as long as broad (2.33-2.84x in Japanese and 2.1-2.6x in European), gaster $3.13 x$ as long as broad (2.4-3.6x in Japanese and 2.3-3.2x in European ), T7 1.4x as long as broad (broader than long to $1.4 \mathrm{x}$ in Japanese and at most as long as broad in European). T. pulcher was treated as a synonym of T.princeps Westwood until Graham (1969) removed it from the synonymy. According to Kamijo (2000) T. pulcher is a very variable species and show characters intermediate between $T$. pulcher and T. princeps Westwood and both the species may eventually prove to be synonymous when further 
specimens from various regions are examined. In the key to the European species by Graham (1969) also the present specimen keyed out in to $T$. pulcher with slight variations in the character of combined length of pedicellus plus flagellum $1.54 \mathrm{x}$ breadth of head (1.3-1.35x in the key), and gaster $1.3 x$ as long as head plus mesosoma combined (not more than $1.2 x$ as long as head plus mesosoma in the key). This is the first report of the species from India. The collection of the species from the high hill ranges of southern Western Ghats prove the occurrence of true palearctic elements in the fragmented forests which experience a temperate climate in most of the seasons.

\section{Heydenia tuberculata Sureshan, 2000 (Image 3)}

2000. Heydenia tuberculata Sureshan, Zoos' Print Journal. XV.2.197. F, India: Karnataka (ZSIK).

Material examined: ZSI/WGRS/IR-INV-2212, 1 male, 5.iv.2012, $10^{\circ} 22^{\prime} 20^{\prime \prime} \mathrm{N} \& 77^{0} 15^{\prime} 0^{\prime \prime} \mathrm{E}$, Vasyapara, Chinnar Wildlife Sanctuary, Idukki District, Kerala, India, coll. P.M. Sureshan.

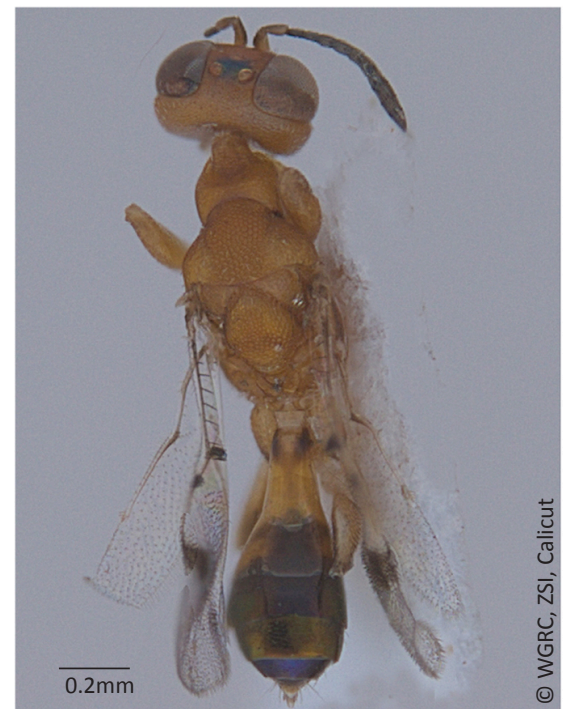

Image 3. Heydenia tuberculata Sureshan, male body in dorsal view.
Description: Male: Length: $1.8 \mathrm{~mm}$. Resembles female in general morphology but differs as follows: Color: head and meososma generally testaceous with dorsal part brown, ocellar triangle black, gaster dark brown with basal part testaceous; tips of hind coxae and femur brown; transverse band of silvery scales across face narrow, less distinct; median tubercle of propodeum not much projecting, less distinct; gaster (including petiole) short, $0,9 x$ as long as head plus mesosoma combined.

Distribution: India: Karnataka, Kerala (present study).

Remarks: The species is unique in having a distinct median ' $Y$ ' shaped carina on propodeum with a curved tubercle at the junction of ' $Y$ ' and was described from a single female holotype collected from the Kodagu District of Karnataka, India and the present specimen is the first record of male of the species and record of the species for the first time from Kerala. Both the specimens are collected by sweeping over dead wood infested with wood boring beetles from forested tracts of southern Western Ghats and are believed to be parasitoids of the wood boring beetles.

\section{REFERENCES}

Gibson, G.A.P., (1997). Chapter 2. Morphology and Terminology, pp. 16-44. In: Gibson, G.A.P., J.T. Huber \& J.B. Woolley (eds.). Annotated Keys to the Genera of Nearctic Chalcidoidea (Hymenoptera). NRC Research Press, Ottawa, Ontario, Canada, 794pp.

Gibson, G.A.P (2003). Phylogenetics and Classification of Cleonyminae (Hymenoptera: Chalcidoidea: Pteromalidae). International Associated Publishers, Gainesville, USA, 339pp.

Graham, M.W.R. de V. (1969). The Pteromalidae of north-western Europe (Hymenoptera: Chalcidoidea). Bulletin of the British Museum (Natural History) (Entomology) 16: 908.

Kamijo, K. (1996). Notes on the genus Cleonymus Latreille (Hymenoptera: Pteromalidae) with descriptions of four new species from Japan. Japan Journal of Entomology 64(4): 745-758.

Kamijo, K. (2000). Japanese species of Trigonoderus (Hymenoptera: Pteromalidae) with descriptions of three new species. Japan Journal of Systematic Entomology 6(2): 173-181. 